\title{
KAJIAN USABILITY APLIKASI CANVA (STUDI KASUS PENGGUNA MAHASISWA DESAIN)
}

\author{
Erisa Adyati Rahmasari ${ }^{1}$, Auria F. Yogananti ${ }^{2}$ \\ 1,2Desain Komunikasi Visual, Fakultas Ilmu Komputer, Universitas Dian Nuswantoro \\ erisa.adyati@dsn.dinus.ac.id ${ }^{1}$, yogananti.au@dsn.dinus.ac.id ${ }^{2}$
}

\begin{abstract}
Abstrak
Kemudahan mendesain saat ini ditawarkan oleh platform desain melalui website maupun aplikasi. Canva merupakan salah satu best platform yang digunakan untuk mendesain. Canva dapat dengan digunakan melalui website dan aplikasi mobile. Canva didesain dengan kelengkapan fitur dan template yang memudahkan seseorang mendesain seperti mendesain poster, kartu ucapan, brosur, infografis hingga presentasi dalam waktu yang singkat. Hal tersebutlah yang membuat Canva digunakan pula oleh mahasiswa. Penelitian ini dilakukan untuk mengetahui usability dari aplikasi Canva dengan tujuan mengetahui pengalaman pengguna dalam hal ini mahasiswa terhadap aplikasi tersebut karena ditemukan ketidakpuasan pada saat menggunakan aplikasi Canva. Metode kualitatif-kuantitatif digunakan untuk mendiskripsikan secara detail hasil wawancara langsung dan hasil angket yang diberikan. Analisa aplikasi menggunakan poin Usability yakni berkaitan dengan learnability, efficiency, memorability, error dan satisfaction untuk mengetahui pengalaman pengguna dan dipadukan dengan metode Important Performance Analysis (IPA). Dari analisa yang dilakukan pada aplikasi Canva diketahui bahwa untuk meningkatkan usability, kemudahan aksesibilitas serta kepuasan pengguna ketika menemukan error dan memperbaiki error harus diperbaiki. Selain itu, aplikasi Canva perlu memperbaiki alur dan akurasi waktu saat penggunaan aplikasi. Poin usability yang perlu dipertahankan adalah kemudahan saat mengenali simbol-simbol, dan sistem serta efisiensi navigasi.
\end{abstract}

Kata Kunci: aplikasi, Canva, desain, usability, user experience

\begin{abstract}
The convenience of design also offered a design platform through a website or application. Canva is one of the best platforms used to design. Canva can be used through the website and mobile application. Canva was designed with the features and templates that can help someone make the design like a poster design, a greeting, brochures, infographic until a presentation in a limited time. Those things made Canva also used by university students. This study was conducted to appraise the usability to learn user experiences, in this case, are students toward the application because dissatisfaction found when Canva application used. The mixed-method is used to describe the detailed result of direct interviews and surveys. The analysis used the usability point associate with learnability, efficiency, memorability, error, and satisfaction to understanding the user experience combined with Important Performance Analysis (IPA). From the analysis that has been done, to increase usability, ease accessibility, and user satisfaction when a user found error and fix error must be repaired. Furthermore, the Canva application needs to correct user flow and time accuracy when using the application. Moreover, Usability points that need to maintain are convenience when recognizing symbols, system, and navigation efficiency.
\end{abstract}

Keywords: Application, Canva, Design, Usability, User Experience 


\section{PENDAHULUAN}

Badan Ekonomi Kreatif (Bekraf) menyampaikan bahwasanya desain komunikasi visual merupakan salah satu sektor yang berkembang dengan pesat. Badan Pusat Statistik (BPS) menyampaikan bahwasannya sektor ini perkembangannya mencapai $8,14 \%$ pada tahun 2017. Perkembangan yang ada juga didukung dengan pesatnya perkembangan teknologi software dalam bidang desain dengan banyak bermunculannya software yang menunjang kebutuhan dalam mendesain. Tidak hanya itu software desain dirancang dapat digunakan untuk mengolah gambar dengan kualitas yang baik dan mempunyai nilai seni yang tinggi. Ada beberapa software desain yang biasanya digunakan untuk mengolah visual dalam desain misalnya Adobe Photoshop, Adobe llustrator, Corel Draw, dan masih banyak yang lain.

Beberapa tahun terakhir kemudahan dalam mendesain tidak hanya ditawarkan oleh software namun juga ditawarkan oleh platform yang berbeda seperti pada website ataupun aplikasi. Secara garis besar selain menawarkan kemudahan dalam mengedit atau mendesain, platform ini juga menawarkan memudahkan dan efisiensi waktu dalam penggunaanya. Adapun beberapa contohnya adalah Canva, RelayThat, Pixlr, Crello, Tyle dan masih banyak yang lain. Canva merupakan salah satu best platform yang digunakan untuk mendesain (Dinita, 2020). Canva adalah platform desain gratis yang dapat dengan mudah membantu penggunanya untuk membuat desain dengan hasil yang profesional menggunakan template desain (Demarest, 2020). Canva memberikan pilihan template yang melimpah namun juga memberikan kesempatan pada pengguna untuk mendesain sendiri dengan menggunakan gambar atau desain yang telah dibuat ke dalam Canva. Canva dapat dengan mudah digunakan pada browser ataupun pada aplikasi mobile.

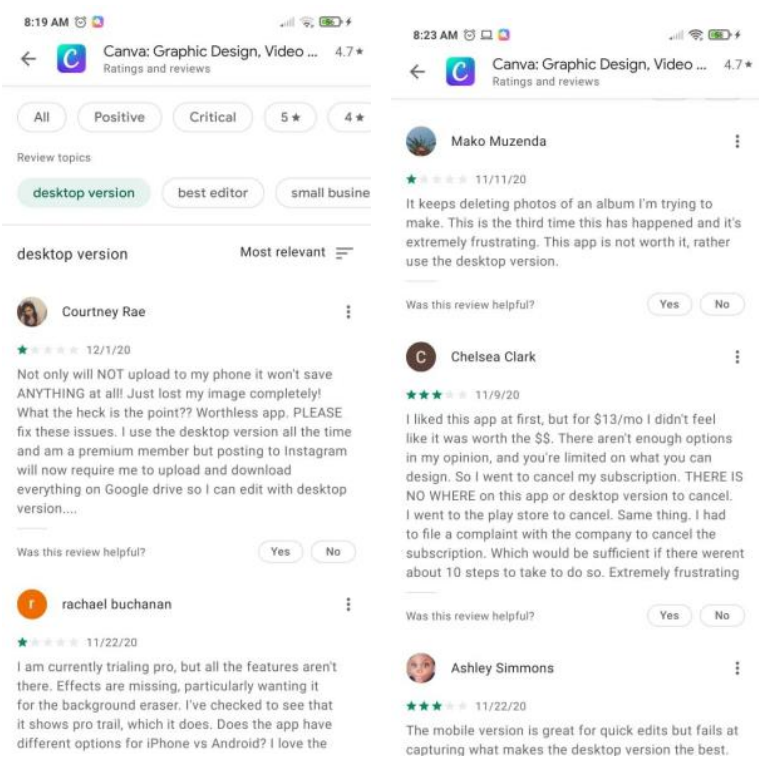

Gambar 1. Review pengguna aplikasi Canva pada topik desktop version [Sumber: google play]

Canva memiliki kelengkapan fitur yang memudahkan seseorang dalam mendesain, misalnya poster, kartu ucapan, brosur, infografis hingga presentasi. Canva memiliki fiturfitur teks dan animasi. Salah satu kelebihan dari Canva adalah kemudahan membuat 
desain dengan drag and group template gambar maupun animasi yang telah tersedia tanpa harus mendesain ulang dari awal, sehingga dengan kemudahan ini dapat menarik orang untuk menggunakannya termasuk mahasiswa.

Beberapa mahasiswa diketahui menggunakan Canva untuk keperluan mendesain presentasi dan feed sosial media, sebagian besar dari mahasiswa merasakan memudahkan dalam membuat desain dengan waktu yang singkat. Mahasiswa menggunakan Canva melalui website daripada aplikasi android karena dirasa kurang memaksimalkan kemampuannya dalam mendesain. Pernyataan tersebut juga didukung dari nilai yang diberikan pada bagian rating \& review di google play yang dapat dilihat pada gambar 1 . Hal tersebut cukup menarik karena bila dilihat pada aplikasi android, aplikasi ini berada pada top 1 grossing dalam kategori art \& design namun ditemukan bahwasanya masih banyak yang ternyata tidak puas dengan versi aplikasi termasuk beberapa mahasiswa yang merasakan ketidakpuasannya saat mendesain melalui aplikasi Canva. Sehingga dalam penelitian ini peneliti berusaha mencari usability pengguna. Usability mempengaruhi pengalaman pengguna atau user experience karena merupakan ukuran yang digunakan untuk mengidentifikasi seberapa mudah sebuah produk itu digunakan oleh penggunanya secara efektif dan efisien (Galits, 2007) dalam hal ini mahasiswa pada saat berinteraksi dengan aplikasi Canva sehingga dapat mengetahui hal-hal apa saja yang mempengaruhi pengalaman pengguna saat berinteraksi dengan aplikasi Canva.

\section{METODE PENELITIAN}

Penelitian menggunakan metode kualitatif-kuantitatif yang nantinya dapat mendeskripsikan secara detail pengalaman pengguna terhadap aplikasi Canva. Data yang digunakan merupakan data hasil wawancara secara tidak langsung dengan memberikan pertanyaan kepada pengguna melalui jejaring internet, memberikan angket melalui google form dan studi literatur. Dalam penelitian ini pendekatan teori usability sebagai bagian dari user experience (UX) dan perhitungan persentase sederhana dan Important Performance Analysis (IPA) digunakan untuk mendapatkan pengalaman pengguna terhadap aplikasi.

Adapun pendekatan teori usability sebagai bagian dari user experience dapat diartikan dengan kemudahan sebuah produk dapat diakses atau digunakan (Nielsen, 2012) sehingga usability memberikan kontribusi yang penting dalam sebuah UX karena merupakan sebuah syarat untuk sebuah produk untuk dapat bertahan. Menurut Nielsen (2012), usability ditentukan oleh 5 komponen:

a. Learnability yaitu seberapa mudah bagi pengguna untuk menyelesaikan tugas pada saat pertama kali menggunakan sebuah produk.

b. Efficiency yaitu setelah pengguna mempelajari desain sebuah produk, seberapa cepat pengguna dapat menyelesaikan tugas yang diberikan.

c. Memorability yaitu pada saat pengguna menggunakan produk kembali, seberapa mudah pengguna menggunakan produk kembali.

d. Errors yaitu berapa banyak kesalahan yang dilakukan pengguna selama dan seberapa cepat pengguna memperbaiki kesalahan tersebut saat berinteraksi dengan produk. 
e. Satisfaction yaitu seberapa besar kepuasan pengguna saat menggunakan dan berinteraksi dengan produk.

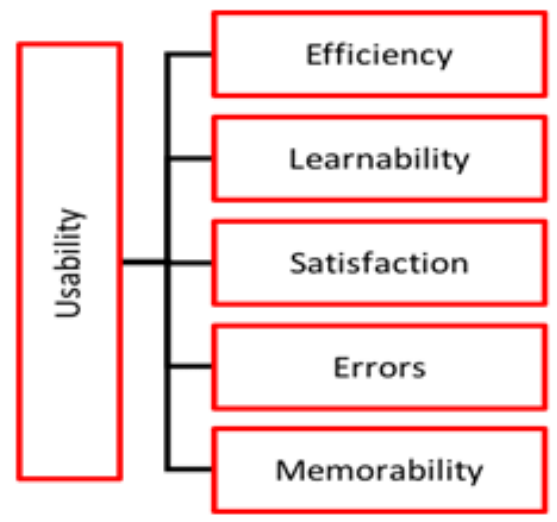

Gambar 2. Komponen usability dalam user experience

[Sumber: Nielsen, 2012]

Tahapan yang akan dilakukan dalam penelitian ini adalah sebagai berikut:

1) Memilih Responden. Adapun responden yang menjadi sumber data pada penelitian ini adalah mahasiswa jurusan desain yang sehari-harinya bersinggungan dengan software desain namun juga menggunakan platform atau aplikasi desain untuk menunjang aktivitasnya. Adapun pengguna yang terlibat sebanyak 35 orang.

2) Melakukan wawancara. Wawancara dilakukan untuk memahami pengetahuan pengguna terhadap aplikasi Canva.

3) Melakukan penyebaran angket. Angket yang diberikan pada responden meminta responden terlebih dahulu melakukan beberapa tugas sehingga saat menjawab pertanyaan, responden diharapkan dapat dengan mudah mengisi pertanyaanpertanyaan yang diajukan. Adapun langkah-langkah yang dilakukan sebelum menjawab pertanyaan angket yang berkaitan dengan Usability adalah sebagai berikut:

a. Buka aplikasi Canva (jika aplikasi belum ada, silahkan menginstal terlebih dahulu aplikasi Canva apa ponsel)

b. Cari kategori dalam eksplore Canva

c. Pilih button all category

d. Pilih poster kemudian pilih event poster

e. Silahkan membuat desain dari blank template

f. (buatlah desain sederhana dengan menggunakan tool desain yang ada)

g. Masukan teks (bebas)

h. Masukan image (bebas)

i. Setelah itu simpan

4) Merekapitulasi dan mendeskripsikan hasil data dan wawancara yang telah dilakukan Canva dengan tetap mengacu pada komponen Usability Jakob Nielsen. 


\section{HASIL DAN PEMBAHASAN}

\subsection{Data Aplikasi Canva}

Dari hasil wawancara yang diberikan, ditemukan bahwasannya seluruh mahasiswa yang menjadi responden mengetahui tentang platform desain Canva. Mahasiswa menggunakan platform Canva melalui website dan aplikasi Android untuk kebutuhan pembuatan presentasi dan pembuatan feed yang akan digunakan di sosial media. Alasan yang diberikan adalah karena platform tersebut telah memberikan efisiensi waktu. Untuk pembuatan tugas, mahasiswa lebih memilih menggunakan software desain seperti Photoshop, Illustrator atau Corel Draw karena dirasa dapat memaksimalkan kemampuan desain yang dimiliki sehingga desain yang dihasilkan dapat sesuai dengan konsep yang dibuat untuk tugas yang diberikan.

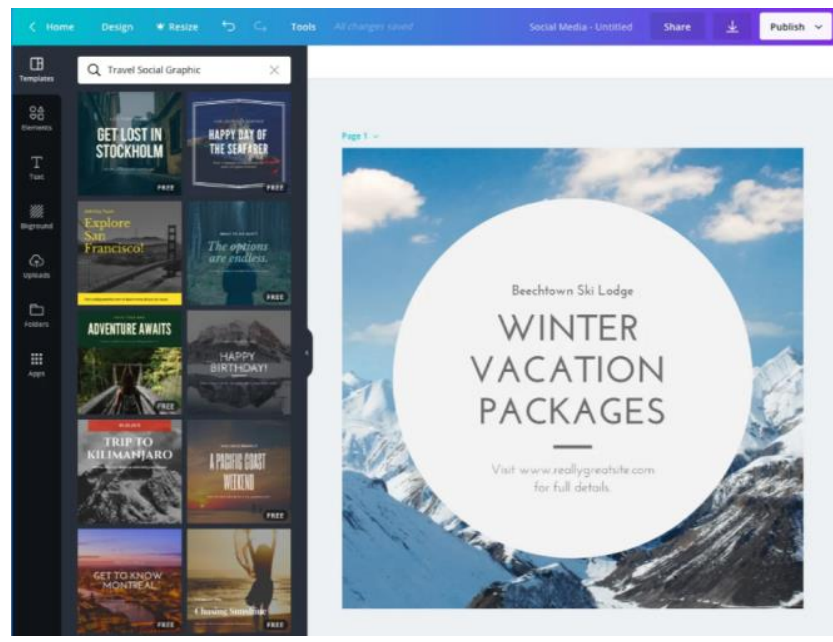

Gambar 3. Tampilan user interface aplikasi Canva [Sumber: canva.com]

Pada saat menggunakan platform Canva responden menyatakan bahwa kemudahan dan kecepatan saat mendesain lebih dirasakan saat menggunakan platform Canva melalui website dibandingkan melalui aplikasi android. Alasannya adalah karena luas tampilan monitor yang jauh lebih besar saat mendesain melalui website yang diakses melalui PC ataupun Laptop sehingga mahasiswa dapat lebih leluasa mengeksplorasi tampilan yang ada. Jika mendesain menggunakan aplikasi berarti monitor yang digunakan adalah monitor smartphone yang jauh lebih kecil. Selain itu, saat menggunakan aplikasi mahasiswa akan menggunakan jari saat mendesain sedangkan bila menggunakan platform Canva melalui PC atau laptop mahasiswa dapat menggunakan mouse sehingga lebih leluasa saat mendesain dan mengedit desain.

\subsection{Data Elemen Usability}

Terdapat 5 elemen dalam Usability yang dijadikan sebagai bahan analisis. Elemen tersebut dipecah menjadi 14 pertanyaan dari angket yang mewakili elemen dalam usability berdasarkan interaksi pengguna aplikasi Canva.

a. Learnability

1. Seberapa mudah Anda dalam mengenali tombol (button) dalam aplikasi Canva? (PENGENALAN SIMBOL APLIKASI) 
2. Seberapa mudah aplikasi Canva digunakan pertama kali, berkaitan dengan urutan perintah diatas? (PENGGUNAAN APLIKASI)

3. Seberapa mudah Anda mengenali sistem dari Canva ketika kalian sudah mendapat pengalaman sebelumnya? (PENGENALAN SISTEM APLIKASI)

4. Seberapa mudah Anda menguasai aplikasi Canva ketika Anda berinteraksi dengan aplikasi ini? (PENGUASAAN MATERI APLIKASI)

b. Efficiency

5. Seberapa mudah dan cepat Anda dalam menggunakan navigasi yang ada dalam aplikasi Canva? (AKSESIBILITAS APLIKASI)

6. Seberapa cepat Anda dalam mengenali dan mempelajari aplikasi Canva hingga dapat menyelesaikan perintah sebelumnya? (AKURASI WAKTU)

7. Seberapa efisien penggunaan tombol/navigasi dalam aplikasi Canva? (EFISIENSI NAVIGASI)

c. Memorability

8. Seberapa mudah mengingat (daya ingat) langkah-langkah menggunakan aplikasi Canva untuk kedua kalinya/ pengalaman kedua menggunakan tombol aplikasi Canva? (DAYA INGAT PENGGUNA APLIKASI)

9. Seberapa relevan tombol terkait dengan perwakilan simbol atau ikon dalam aplikasi Canva? (RELEVANSI NAVIGASI)

10. Seberapa mudah Anda mengingat visual berkait dengan langkah-langkah perintah yang dikerjakan sebelumnya? (VISUAL SEQUENCE APLIKASI)

d. Error

11. Apakah kalian menemukan error pada saat menggunakan aplikasi Canva? (SLIP ERROR)

12. Jika ada kesalahan saat menggunakan aplikasi ini apakah Anda dengan mudah memperbaiki error atau kesalahan tersebut? (MISTAKE ERROR)

e. Satisfaction

13. Bagaimana perasaan Anda pada saat menggunakan aplikasi Canva? (REAKSI PENGGUNA APLIKASI)

14. Bagaimana respon Anda ketika menggunakan aplikasi Canva? (RESPONSE PENGGUNA APLIKASI)

Dari 5 kategori yang ada kelimanya kemudian dibagi menjadi menjadi 2 kategori yaitu Performance: Learnability dan Efficiency; dan Importance: Memorability, error dan Satisfaction. Sehingga masing-masing kategori berisi 7 pertanyaan (Atribut) Setelah tahapan pembuatan pertanyaan yang mewakili elemen Usability. Pertanyaan tersebut digunakan untuk menilai 35 mahasiswa ketika berinteraksi atau menggunakan aplikasi Canva. 15 pertanyaan mewakili setiap sub penilaian dalam elemen Usability. Responden yang dijadikan subjek penelitian merupakan mahasiswa yang dirandom dalam kategori yang belum pernah sama sekali menggunakan dan kategori yang sudah pernah menggunakan aplikasi Canva. Berikut data tabulasi dan statistik dari hasil wawancara dan penyebaran angket terhadap pengguna aplikasi Canva: 
a) Learnability

1. Pengenalan Simbol Aplikasi

\begin{tabular}{|l|l|l|l|}
\hline Pertanyaan & \multicolumn{3}{|l|}{$\begin{array}{l}\text { Seberapa mudah Anda dalam mengenali tombol (button) dalam } \\
\text { aplikasi Canva? }\end{array}$} \\
\hline Jawaban & Mudah & Sedang & Sukar \\
\hline Frekuensi & 23 & 12 & \\
\hline Prosentase & $65,7 \%$ & $34,3 \%$ & - \\
\hline
\end{tabular}

2. Penggunaan Aplikasi

\begin{tabular}{|l|l|l|l|}
\hline Pertanyaan & \multicolumn{3}{|l|}{$\begin{array}{l}\text { Seberapa mudah aplikasi Canva digunakan pertama kali, berkaitan } \\
\text { dengan urutan perintah diatas? }\end{array}$} \\
\hline Jawaban & Mudah & Sedang & Sukar \\
\hline Frekuensi & 17 & 16 & 2 \\
\hline Prosentase & $48,6 \%$ & $45,7 \%$ & $5,7 \%$ \\
\hline
\end{tabular}

3. Pengenalan Sistem Aplikasi

\begin{tabular}{|l|l|l|l|}
\hline Pertanyaan & \multicolumn{4}{|l|}{$\begin{array}{l}\text { Seberapa mudah Anda mengenali sistem dari Canva ketika kalian } \\
\text { sudah mendapat pengalaman sebelumnya? }\end{array}$} \\
\hline Jawaban & Mudah & Sedang & Sukar \\
\hline Frekuensi & 22 & 13 & \\
\hline Prosentase & $62,9 \%$ & $37,1 \%$ & - \\
\hline
\end{tabular}

4. Penguasaan Materi Aplikasi

\begin{tabular}{|l|l|l|l|}
\hline Pertanyaan & \multicolumn{4}{l|}{ Seberapa mudah Anda menguasai aplikasi Canva ketika Anda } \\
berinteraksi dengan aplikasi ini?
\end{tabular}

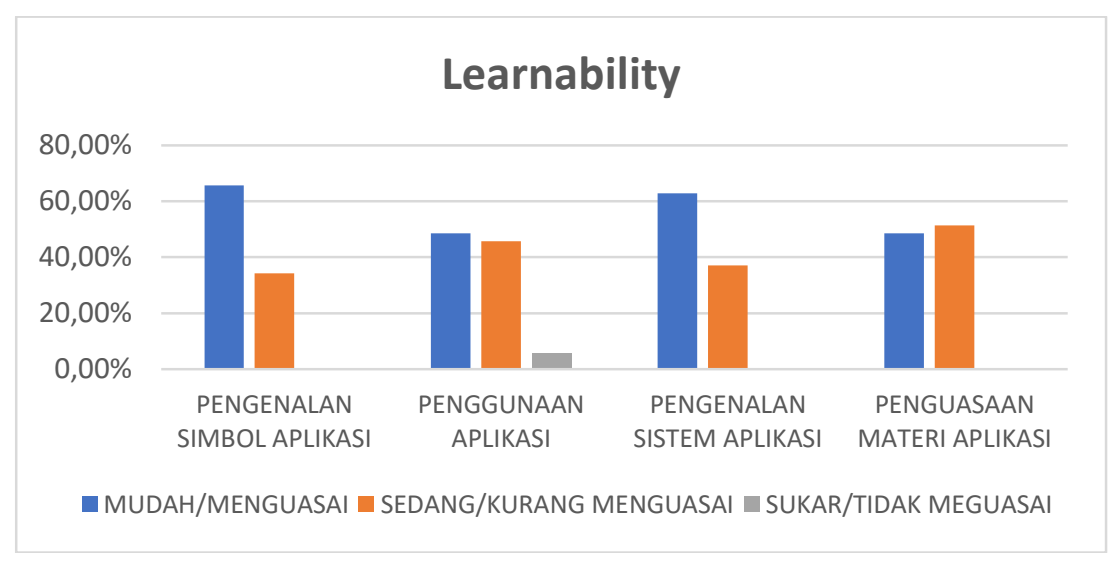

Gambar 4. Grafik data Learnability

[Sumber: Dokumentasi Penulis]

Data yang didapat pada poin learnability menunjukkan bahwa setiap aspek yang ada dalam learnability yaitu pengenalan simbol (button) pada aplikasi, penggunaan aplikasi, pengenalan sistem aplikasi dan penguasaan materi aplikasi menunjukkan hasil yang baik. Sebanyak $65,7 \%$ responden dapat dengan mudah mengenali button pada aplikasi. 
Untuk penggunaan pertama kali berkaitan dengan tugas yang diberikan, sebanyak $48,6 \%$ merasakan kemudahan dalam mengerjakan urutan tugas yang diberikan. Selain itu $62,9 \%$ responden juga dapat dengan mudah mengenali sistem yang dimiliki aplikasi Canva. Nilai yang berbeda ada pada kemudahan menguasai aplikasi saat berinteraksi karena sebanyak 51,4\% responden merasa kurang menguasai aplikasi Canva. Bila diperhatikan lebih mendalam dari keempat poin learnability tiga poin memiliki $0 \%$ responden yang tidak merasakan sukar saat mengenali tombol (button), tidak merasa sukar dalam mengenali sistem dan berinteraksi dengan aplikasi. Hanya pada poin kemudahan penggunaan saat pertama kali menggunakan berkaitan dengan urutan pengerjaan yang dirasakan masih sukar untuk sekitar $5,7 \%$ responden.

\section{b) Efficiency}

5. Aksesibilitas Aplikasi

\begin{tabular}{|l|l|l|l|}
\hline Pertanyaan & \multicolumn{3}{|l|}{$\begin{array}{l}\text { Seberapa mudah dan cepat Anda dalam menggunakan navigasi } \\
\text { yang ada dalam aplikasi Canva? }\end{array}$} \\
\hline Jawaban & Cepat & Sedang & Lambat \\
\hline Frekuensi & 12 & 23 & \\
\hline Prosentase & $34,3 \%$ & $65,7 \%$ & - \\
\hline
\end{tabular}

6. Akurasi Waktu

\begin{tabular}{|l|l|l|l|}
\hline Pertanyaan & \multicolumn{3}{|l|}{$\begin{array}{l}\text { Seberapa cepat Anda dalam mengenali dan mempelajari aplikasi } \\
\text { Canva hingga dapat menyelesaikan perintah sebelumnya? }\end{array}$} \\
\hline Jawaban & Cepat & Sedang & Lambat \\
\hline Frekuensi & 18 & 17 & \\
\hline Prosentase & $51,4 \%$ & $48,6 \%$ & - \\
\hline
\end{tabular}

7. Efisiensi Navigasi

\begin{tabular}{|l|l|l|l|}
\hline Pertanyaan & \multicolumn{3}{|l|}{$\begin{array}{l}\text { Seberapa efisien penggunaan tombol/navigasi dalam aplikasi } \\
\text { Canva? }\end{array}$} \\
\hline Jawaban & Efisien & Kurang Efisien & Tidak Efisien \\
\hline Frekuensi & 31 & 4 & \\
\hline Prosentase & $88,6 \%$ & $11,4 \%$ & - \\
\hline
\end{tabular}

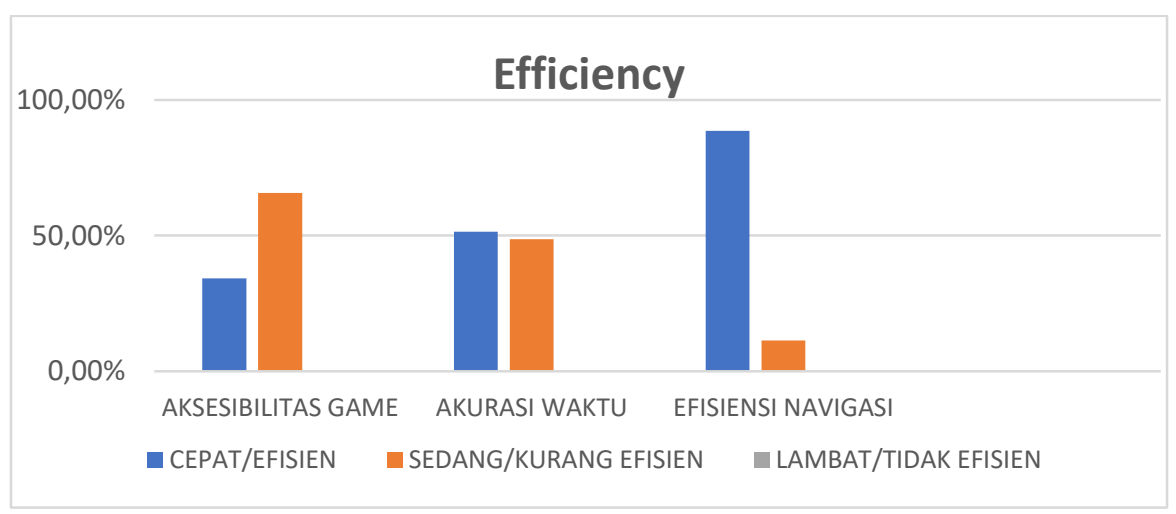

Gambar 5. Grafik data efficiency

[Sumber: Dokumentasi Penulis] 
Data yang didapat untuk poin efficiency menunjukkan bahwa responden dapat dengan cepat mengakses navigasi yang ada dalam aplikasi, kecepatan dalam mengenali dan mempelajari aplikasi serta dan efisiensi penggunaan tombol (navigasi) pada aplikasi Canva menunjukkan nilai yang baik. Terdapat $34,3 \%$ responden yang merasakan kemudahan dalam menggunakan aplikasi. 51,4\% dapat dengan cepat mengenali dan mempelajari aplikasi Canva sebelum mengerjakan tugas yang diberikan dan terakhir $88,6 \%$ pengguna merasakan bahwa tombol (navigasi) yang dimiliki oleh aplikasi Canva efisien untuk digunakan.

c) Memorability

8. Daya Ingat Pengguna Aplikasi

\begin{tabular}{|l|l|l|l|}
\hline Pertanyaan & $\begin{array}{l}\text { Seberapa mudah mengingat (daya ingat) langkah-langkah } \\
\text { menggunakan aplikasi Canva untuk kedua kalinya/ pengalaman } \\
\text { kedua menggunakan tombol aplikasi Canva? }\end{array}$ \\
\hline Jawaban & Kuat & Kurang Kuat & Tidak Kuat \\
\hline Frekuensi & 26 & 9 & \\
\hline Prosentase & $74,3 \%$ & $25,7 \%$ & - \\
\hline
\end{tabular}

9. Relevansi Navigasi

\begin{tabular}{|l|l|l|l|}
\hline Pertanyaan & \multicolumn{4}{|l|}{$\begin{array}{l}\text { Seberapa relevan tombol terkait dengan perwakilan simbol atau } \\
\text { ikon dalam aplikasi Canva? }\end{array}$} \\
\hline Jawaban & Relevan & Kurang Relevan & Tidak Relevan \\
\hline Frekuensi & 28 & 7 & \\
\hline Prosentase & $80 \%$ & $20 \%$ & - \\
\hline
\end{tabular}

10. Visual Sequence Aplikasi

\begin{tabular}{|l|l|l|l|}
\hline Pertanyaan & \multicolumn{4}{|l|}{$\begin{array}{l}\text { Seberapa mudah Anda mengingat visual berkait dengan langkah- } \\
\text { langkah perintah yang dikerjakan sebelumnya? }\end{array}$} \\
\hline Jawaban & Kuat & Kurang Kuat & Tidak Kuat \\
\hline Frekuensi & 27 & 7 & 1 \\
\hline Prosentase & $77,1 \%$ & $20 \%$ & $2,9 \%$ \\
\hline
\end{tabular}

\section{Memorability}

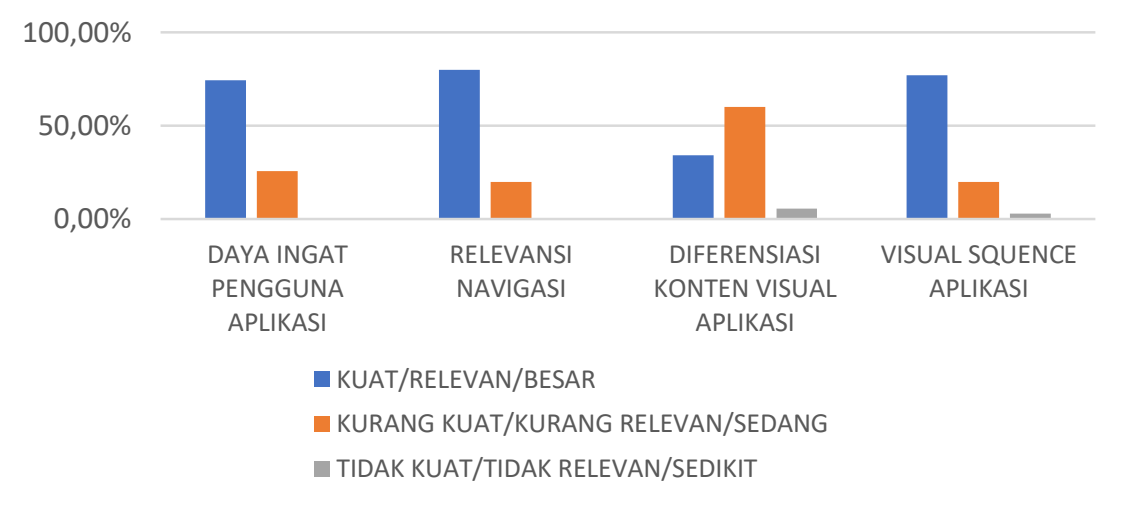

Gambar 6. Grafik data memorability

[Sumber: Dokumentasi Penulis] 
Data yang didapat pada poin memorability menunjukkan bahwa setiap aspek yang ada dalam memorability yaitu daya ingat dalam penggunaan aplikasi, relevansi navigasi, diferensiasi konten visual, dan visual sequence aplikasi menunjukkan nilai yang baik. Pada tingkat kemudahan dalam mengingat saat menggunakan untuk kedua kali, $74,3 \%$ responden memiliki daya ingat yang kuat terhadap aplikasi Canva. Terkait relevansi dan navigasi yang digunakan $80 \%$ responden merasa navigasi yang ada sudah relevan. Untuk perbedaan konten visual $60 \%$ responden merasa perbedaan fitur dalam aplikasi tidak begitu besar dan untuk kemudahan mengingat visual terkait langkah-langkah dalam pengerjaan $77 \%$ responden merasakan ingatan yang kuat saat menggunakan aplikasi untuk kedua kalinya.

d) Error

11. Error Slip

\begin{tabular}{|l|l|l|l|}
\hline Pertanyaan & \multicolumn{3}{|l|}{$\begin{array}{l}\text { Apakah kalian menemukan error pada saat menggunakan aplikasi } \\
\text { Canva? }\end{array}$} \\
\hline Jawaban & Banyak & Sedang & Sedikit \\
\hline Frekuensi & 4 & 8 & 23 \\
\hline Prosentase & $11,4 \%$ & $22,9 \%$ & $65,7 \%$ \\
\hline
\end{tabular}

12. Error Mistake

\begin{tabular}{|l|l|l|l|}
\hline Pertanyaan & \multicolumn{3}{|l|}{$\begin{array}{l}\text { Jika ada kesalahan saat menggunakan aplikasi ini apakah Anda } \\
\text { dengan mudah memperbaiki error atau kesalahan tersebut? }\end{array}$} \\
\hline Jawaban & Mudah & Sedang & Sukar \\
\hline Frekuensi & 15 & 17 & 3 \\
\hline Prosentase & $42,9 \%$ & $48,6 \%$ & $8,6 \%$ \\
\hline
\end{tabular}

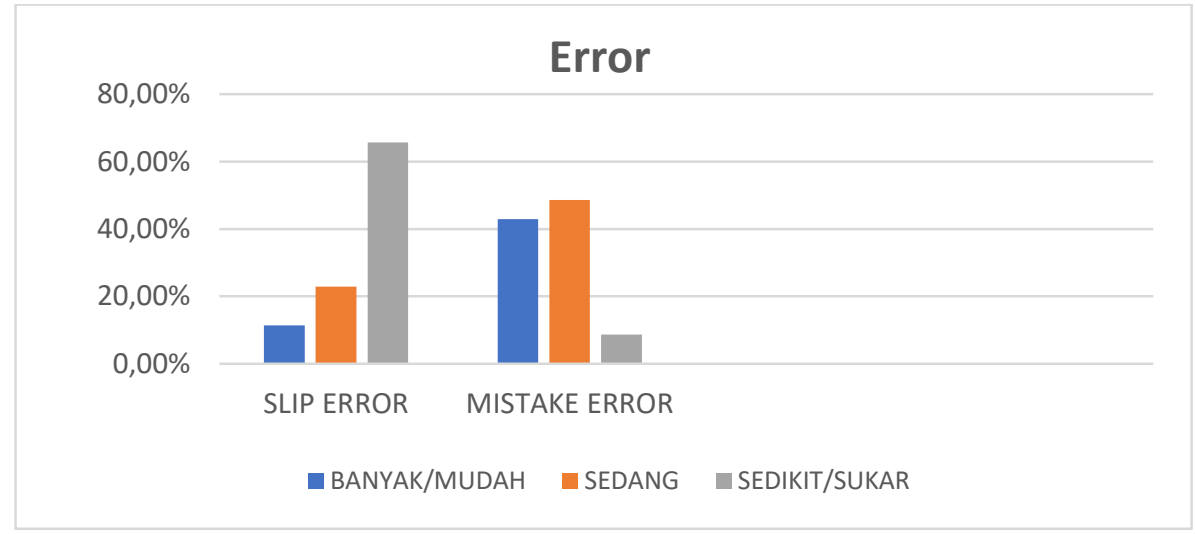

Gambar 7. Grafik data error

[Sumber: Dokumentasi Penulis]

Data yang didapat pada poin error menunjukkan bahwa setiap aspek yang ada didalamnya yaitu error slip dan error mistake memiliki hasil yang berbeda. Error slip menunjukkan hasil yang baik sedangkan error mistake menunjukkan hasil yang sedang. Pada saat responden menggunakan aplikasi Canva 65,7\% menemukan sedikit error saat menggunakan aplikasi Canva. Sedangkan untuk kemudahan saat memperbaiki error atau kesalahan yang ditemukan, 48,6 \% merasakan tidak terlalu mudah ataupun sukar 
dalam memperbaiki. Dapat dilihat pula dalam grafik bahwa tidak ada responden yang merasa sukar saat menemukan error dan memperbaiki error pada saat menggunakan aplikasi Canva.

\section{e) Satisfaction}

13. Reaksi Pengguna Terhadap Aplikasi

\begin{tabular}{|l|l|l|l|}
\hline Pertanyaan & \multicolumn{3}{|l|}{ Bagaimana perasaan Anda pada saat menggunakan aplikasi Canva? } \\
\hline Jawaban & Senang & Sedih & Kecewa \\
\hline Frekuensi & 35 & & \\
\hline Prosentase & $100 \%$ & - & - \\
\hline
\end{tabular}

14. Respon Pengguna Terhadap Aplikasi

\begin{tabular}{|l|l|l|l|}
\hline Pertanyaan & \multicolumn{3}{|l|}{ Bagaimana respon Anda ketika menggunakan aplikasi Canva? } \\
\hline Jawaban & Baik & Kurang Baik & Tidak Baik \\
\hline Frekuensi & 33 & 2 & \\
\hline Prosentase & $94,3 \%$ & $5,7 \%$ & - \\
\hline
\end{tabular}

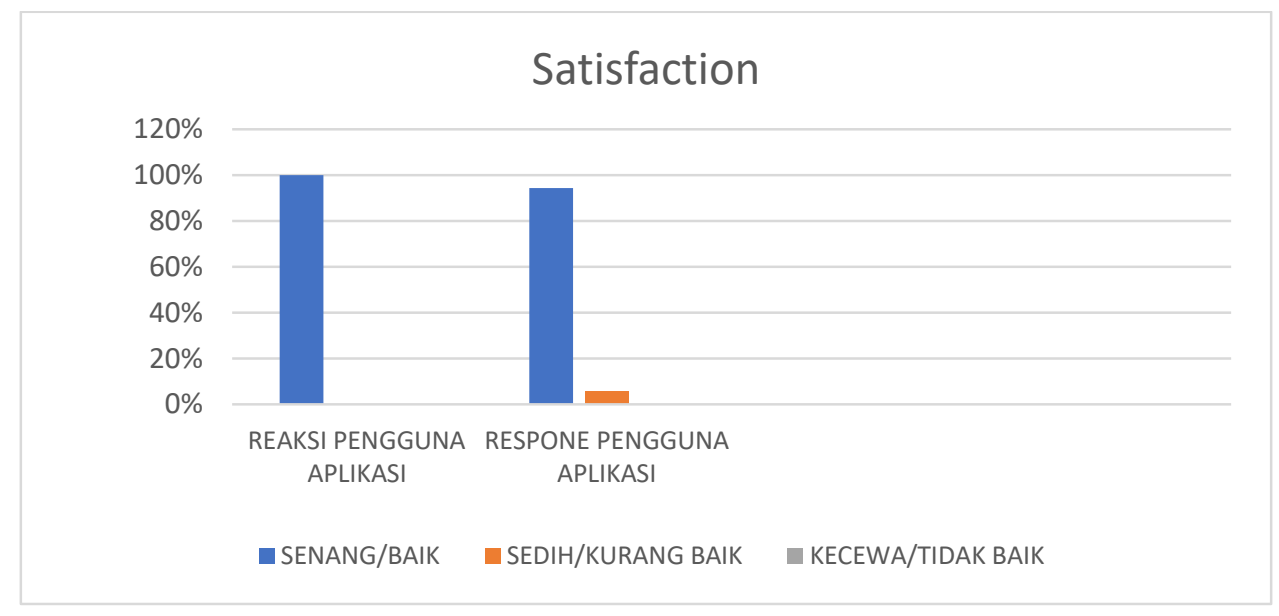

Gambar 8. Grafik data Satisfaction

[Sumber: Dokumentasi Penulis]

Data yang didapat pada poin satisfaction berkaitan dengan perasaan yang dirasakan responden dan respon ketika menggunakan aplikasi sangat baik. $100 \%$ responden atau seluruh responden yang ada merasakan perasaan yang senang saat menggunakan aplikasi Canva dan 94,3\% merespon baik aplikasi Canva. Hasil ini cukup fantastis karena hampir seluruh responden merasakan kepuasan saat menggunakan aplikasi Canva.

Dari analisa sederhana yang telah ada, penulis melakukan analisa lanjutan menggunakan Important Performance Analysis (IPA) yang dibagi menjadi 3 Tahap yaitu: 
Tahap I Menentukan tingkat kesesuaian Performance dan Importance.

Tabel 1 Tingkat Kesesuaian Performance dan Importance [Sumber: Dokumentasi Penulis]

\begin{tabular}{|c|c|c|c|}
\hline No. Atribut & $\mathrm{Xi}$ & $\mathrm{Yi}$ & Tingkat Kesesuaian \\
\hline A1 & 93 & 96 & 0.97 \\
\hline A2 & 85 & 98 & 0.87 \\
\hline A3 & 92 & 96 & 0.96 \\
\hline A4 & 87 & 90 & 0.97 \\
\hline A5 & 82 & 82 & 1.00 \\
\hline A6 & 88 & 105 & 0.84 \\
\hline A7 & 101 & 103 & 0.98 \\
\hline SUM & 628 & 670 & 0.94 \\
\hline
\end{tabular}

Dari data yang didapat dan diolah pada tabel 1 dapat dilihat bahwasanya tingkat kesesuaian antara Performance dan Importance secara keseluruhan, dari Atribut (Pertanyaan) nomor 1 hingga 7 menghasilkan nilai 0.94. Bila dilihat dari kriteria penilaian keseluruhan:

$0.81-1.00$ Sangat Baik

$0.66-0.80$ Baik

$0.51-0.65$ Cukup Baik

$0.35-0.50$ Kurang Baik

$0.00-0.34$ Sangat Tidak Baik

Maka pada tahap pertama hasil yang didapat adalah sangat baik

\section{Tahap II Analisa Kuadran.}

Analisa ini dilakukan untuk mengetahui rata-rata tingkat penilaian untuk setiap atribut pertanyaan. Nilai rata-rata inilah yang akan digunakan sebagai batas sumbu $x$ dan y pada saat menentukan rata-rata penilaian performance dan importance untuk keseluruhan atribut. Didapat rata-rata Performance adalah sebesar 2.56 dan rata-rata Importance adalah 2.73 .

Tabel 2 Tabel nilai rata-rata Performance dan Importance [Sumber: Dokumentasi Penulis]

\begin{tabular}{|c|c|c|c|c|}
\hline No. & skor & Rata2 $\mathrm{Xi}$ & skor & Rata-rata Yi \\
\hline A1 & 93 & 2.66 & 96 & 2.74 \\
\hline A2 & 85 & 2.43 & 98 & 2.80 \\
\hline A3 & 92 & 2.63 & 96 & 2.74 \\
\hline A4 & 87 & 2.49 & 90 & 2.57 \\
\hline A5 & 82 & 2.34 & 82 & 2.34 \\
\hline A6 & 88 & 2.51 & 105 & 3.00 \\
\hline A7 & 101 & 2.89 & 103 & 2.94 \\
\hline & 628 & 2.56 & 670 & 2.73 \\
\hline
\end{tabular}


Tahap III Rata-rata Tingkat Performance dan Importance.

Data yang didapat pada rata-rata Performance (Xi) dan Importance (Yi) kemudian diolah menggunakan SPSS dengan hasil yang dapat dilihat pada gambar 9.

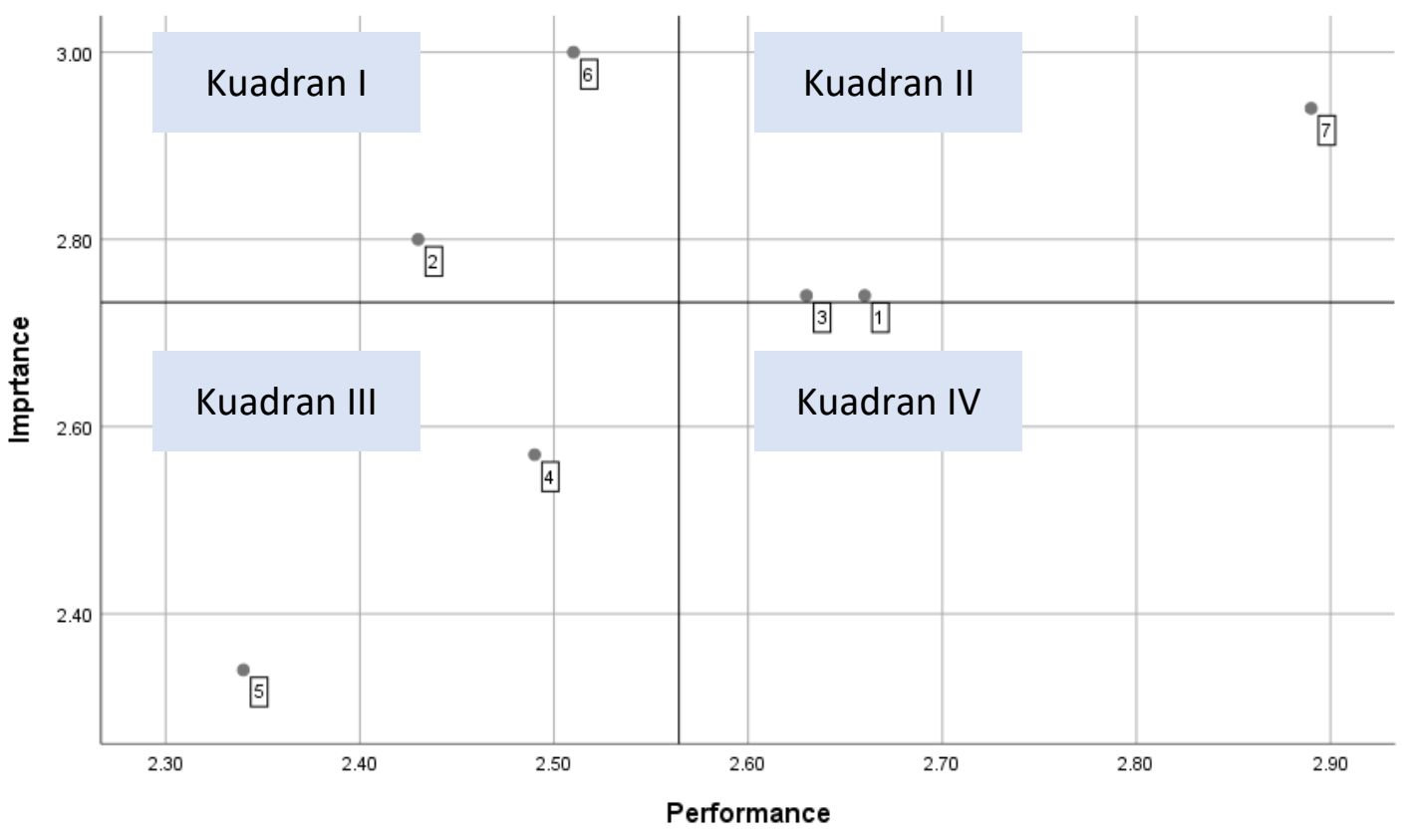

Gambar 9. Grafik Kuadran IPA

[Sumber: Dokumentasi Penulis]

Kuadran IPA untuk usability aplikasi Canva adalah:

Kuadran I, Prioritas Utama yang dijadikan acuan untuk peningkatan kualitas adalah atrtibut 2 dan 6 . Atribut 2 adalah urutan atau langkah saat menggunakan aplikasi dari awal login hingga menyelesaikan tugas yang dikerjakan dan simbol serta icon yang digunakan sebagai tombol dalam aplikasi. Atribut 6 adalah akurasi waktu yang digunakan saat membuat desain pada aplikasi dan perasaan pengguna saat menggunakan aplikasi.

Kuadran II, Atribut yang perlu dipertahankan kualitasnya adalah atribut 1, 3 dan 7. Atribut 1 adalah kemudahan pengguna saat mengenai simbol simbol untuk pengalaman menggunakan aplikasi untuk kedua kalinya. Atribut 3 adalah kemudahan mengenali sistem pada aplikasi dan mengingat langkah-langkah saat menggunakan aplikasi untuk kedua kalinya. Atribut 7 adalah kemudahan efisiensi navigasi ketika menggunakan aplikasi Canva.

Kuadran III, Atribut yang dianggap perlu diperbaiki karena kurang memuaskan adalah atribut 4 dan 5 . Atribut 4 adalah kepuasan pengguna saat berinteraksi yang berkaitan dengan error yang ditemukan saat menggunakan aplikasi Canva. Atribut 5 adalah kemudahan aksesibilitas aplikasi serta seberapa mudah dan cepat Anda dalam menggunakan navigasi dan perbaikan saat terjadinya error. 


\section{KESIMPULAN}

Dari data yang didapat berkaitan dengan usability aplikasi Canva yang digunakan oleh mahasiswa, ditemukan bahwasannya secara garis besar melalui perhitungan sederhana didapatkan hasil yang baik pada penggunaan aplikasi Canva. Namun setelah diolah kembali menggunakan Important Performance Analysis (IPA) sebaran hasil data menunjukkan hal yang berbeda.

Usability aplikasi Canva yang perlu diperbaiki dari hasil kuadran IPA adalah kemudahan aksesibilitas aplikasi serta kepuasan pengguna ketika menemukan error serta memperbaiki error yang terjadi saat berinteraksi dengan aplikasi Canva. Untuk peningkatan kualitas usability, aplikasi Canva perlu memperbaiki urutan atau alur saat penggunaan aplikasi serta akurasi waktu saat pengguna menggunakan aplikasi. Sedangkan poin usability yang perlu dipertahankan adalah kemudahan saat mengenali simbol-simbol yang dimiliki, kemudahan saat mengenali sistem serta efisiensi navigasi. Apabila poin-poin perbaikan dan poin-poin yang perlu ditingkatkan diolah lebih baik lagi, aplikasi Canva tentunya akan memiliki usability yang sangat baik sehingga dapat digunakan secara maksimal pula oleh mahasiswa.

\section{DAFTAR PUSTAKA}

Demarest, A. A. (2020, Sep 19). What is Canva? A guide to the graphic design platform's features and capabilities. Retrieved Dec 04, 2020, from https://www.businessinsider.com/what-is-Canva?r=US\&IR=T

Dinita, M. (2020, August 20). 12 Tools to Create an Infographic in 30 Minutes (Design Skills or Not). Retrieved 12 4, 2020, from https://buffer.com/: https://windowsreport.com/infographics-software/

Galits, W. O. (2007). The Essential Guide to User Interface Design: An Introduction to GUI Design Principles and Techniques (Third Edition ed.). Indianapolis: Wiley Publishing, Inc.

Garrett, J. J. (2011). The Elements of User Experience: User-Centered Design for the Web and Beyond (Second Edition ed.). Berkeley, CA: New Riders.

Nielsen, J. (2012, January 3). Usability 101: Introduction to Usability. Retrieved December 11, 2020, from www.nngroup.com: https://www.nngroup.com/articles/usability-101-introduction-to-usability/

Norman, D., \& Nielsen, J. (n.d.). The Definition of User Experience (UX). Retrieved December 11, 2020, from https://www.nngroup.com/: https://www.nngroup.com/articles/definition-user-experience/

Wesolko, D. (2016, June 15). Peter Morville's User Experience Honeycomb. Retrieved December 11, 2020, from medium.com: https://medium.com/@danewesolko/peter-morvilles-user-experiencehoneycomb-904c383b6886 